\title{
Aseptic addition method for Lactobacillus casei assay of folate activity in human serum
}

\author{
VICTOR HERBERT \\ From the Department of Haematology, The Mount Sinai Hospital, \\ New York, U.S.A.
}

SYNOPSIS An 'aseptic addition' method is described for microbiological assay with Lactobacillis casei of folate activity in human serum. It has the following advantages over the previously reported ${ }_{-}^{\circ}$ 'standard' method. 1 The manipulations involved in the assay are halved, by deleting autoclaving $\vec{N}$ of serum in buffers. 2 The use of $1 \mathrm{~g} . \%$ ascorbate better preserves serum folates than the lowero amounts of ascorbate which are the maximum quantities usable in the standard methods. 3 Only $0.3 \mathrm{ml}$. of serum is required $(0 \cdot 1 \mathrm{ml}$. for one sample; $0.2 \mathrm{ml}$. for its duplicate).

Herbert, Wasserman, Frank, Pasher, and Baker in 1959 reported that folate deficiency could be measured in man using microbiological assay of serum folate activity with Lactobacillus casei. Many other workers have confirmed this work (see review by Herbert, 1965). Various minor modifications of the methodology described by Baker, Herbert, Frank, Pasher, Hutner, Wasserman, and Sobotka (1959) and Herbert (1961) have been reported, including several which appeared in this Journal (Waters and Mollin, 1961; Chanarin and Berry, 1964; Spray, 1964).

It was indicated in the recent past (Herbert, 1964) that the 'aseptic addition' method for microbiological assay with $L$. casei of serum folate has a number of advantages over the 'standard' method. These advantages include halving the manipulations involved in the assay by deleting the step involving autoclaving of serum in buffer; allowing the use of $1 \mathrm{ml}$. of $1 \mathrm{~g}$. $\%$ ascorbate, which better preserves serum folates than do the lower amounts of ascorbate used in the standard method, requiring only $0.3 \mathrm{ml}$. of serum $(0 \cdot 1 \mathrm{ml}$. for one sample; $0.2 \mathrm{ml}$. for its duplicate), an especially valuable point when infants are under study.

\section{METHOD}

PREPARATION OF SERUM SAMPLES Blood is obtained from fasting subjects using either acid-washed sterile syringes, disposable plastic syringes, or Vacutainers ${ }^{1}$ no. 3200 to ensure freedom from contamination with traces of folate. The blood is allowed to stand for approximately three hours at room temperature (in the original Vacutainer Received for publication 3 August 1965

${ }^{1}$ Becton, Dickinson and Co., Rutherford, N.J. or after transfer of blood from syringes to acid-washed screw-top tubes). The clots are 'rimmed' with glass rods $\ominus$ or wooden applicator sticks, the tubes centrifuged for five minutes at 3,000 r.p.m. and the supernatant serumaspirated with acid-washed or disposable pipettes and frozen at $-20^{\circ} \mathrm{C}$. until assay. On the day of assay, the sera are thawed. A $0.1 \mathrm{ml}$. and a $0.2 \mathrm{ml}$. aliquot of serum is added aseptically to autoclaved solutionso containing $5 \mathrm{ml}$. of double-strength medium (see Table I), $\varrho$ $4 \mathrm{ml}$. of de-ionized water ${ }^{2}$, and $1 \mathrm{ml}$. of phosphate buffer $\overrightarrow{\overrightarrow{7}}$ (containing $1 \mathrm{~g}$. ascorbic acid per $100 \mathrm{ml}$. buffer) (see 3 Table II).

MAINTENANCE OF ASSAY ORGANISM AND PREPARATION OF INOCUlA $L$. casei, ATTC (American Type Cultureo Collection) no. 7469 (obtainable for $\$ 5$ in either lyophilized or agar slant culture from American Type CultureCollection, 2112 M Street, Washington, D.C.) is main-ồ tained in the medium described in Table III and stored 3 as a liquid culture at $4^{\circ} \mathrm{C}$. We have carried our currento culture in liquid medium for six years, transferring it every two weeks to fresh maintenance medium, and no mutation has yet occurred. Liquid culture is technically simpler than the agar-slant culture used by a number of 0 investigators.

De-ionized water ${ }^{2}$ is used for preparation of all $N$ media and buffers. It is free of folate and more easily prepared than distilled water. Furthermore, the heavyo metal ions in distilled water have the undesirable ability to accelerate oxidation of the ascorbic acid in the buffer.

Five hundred $\mathrm{ml}$. of maintenance medium (Table III) is generally prepared at one time and dispensed in $10 \mathrm{ml}$. $^{+}$ aliquots into 50 screw-capped tubes. The tubes, with screw caps loosely affixed, are autoclaved for 30 minutes at $118^{\circ} \mathrm{C}$. They are then allowed to cool, the screw caps

${ }^{2}$ Tap water passed through a Barnstead Bantam standard demineral izer cartridge no. 0802 (Barnstead Still and Sterilizer Co., Boston, Mass). 
TABLE I

ASSAY MEDIUM

\begin{tabular}{|c|c|c|}
\hline Constituent & $\begin{array}{l}\text { Amount for } \\
4 \text { l. of Double- } \\
\text { strength } \\
\text { Medium }\end{array}$ & $\begin{array}{l}\text { Concentration } \\
\text { in Final Volume } \\
\text { (mg.\%) }\end{array}$ \\
\hline $\begin{array}{l}\text { Hy-case }(1) \\
\text { L-tryptophan } \\
\text { Adenine }(2,3) \\
\text { Guanine } \mathrm{HCl}(2,3) \\
\text { Uracil }(2,3) \\
\text { Xanthine }(2,3) \\
\text { L-asparagine } \mathrm{H}_{2} \mathrm{O} \\
\text { L-cysteine } \mathrm{HCl}(4) \\
\text { Riboflavin }(2,5,6) \\
\text { Para-aminobenzoic acid }(2,5) \\
\text { Pyridoxine } \mathrm{HCl}(2,5,6) \\
\text { Thiamine } \mathrm{HCl}(2,5) \\
\text { Ca pantothenate }(2,5) \\
\text { Nicotinic acid }(2,5) \\
\text { Biotin }(2,6,7) \\
\text { Glucose } \\
\text { Tween } 80(8) \\
\text { Glutathione (reduced) } \\
\text { Salt mix }(9) \\
\mathrm{Na}_{\text {acetate (anhydrous) }} \\
\mathrm{K}_{2} \mathrm{HPO}_{4} \\
\mathrm{KH}_{2} \mathrm{PO}_{4} \\
\mathrm{MnSO}_{4} \mathrm{H}_{2} \mathrm{O} \text { (10) }\end{array}$ & $\begin{array}{l}40 \mathrm{~g} . \\
0 \cdot 8 \mathrm{~g} . \\
4 \mathrm{ml} . \\
4 \mathrm{ml} . \\
4 \mathrm{ml} . \\
8 \mathrm{ml} . \\
2.4 \mathrm{~g} . \\
2 \mathrm{~g} . \\
4 \mathrm{ml} . \\
8 \mathrm{ml} . \\
16 \mathrm{ml} . \\
1.6 \mathrm{ml} . \\
3.2 \mathrm{ml} . \\
3.2 \mathrm{ml} . \\
1 \mathrm{ml} . \\
160 \mathrm{~g} . \\
4 \mathrm{ml} . \\
20 \mathrm{mg} . \\
40 \mathrm{ml} . \\
160 \mathrm{~g} . \\
4 \mathrm{~g} . \\
4 \mathrm{~g} . \\
0.8 \mathrm{~g} .\end{array}$ & $\begin{array}{c}500 \\
10 \\
0 \cdot 5 \\
0 \cdot 5 \\
0 \cdot 5 \\
1 \cdot 0 \\
30 \\
25 \\
0 \cdot 05 \\
0 \cdot 1 \\
0 \cdot 2 \\
0 \cdot 02 \\
0 \cdot 04 \\
0 \cdot 04 \\
0 \cdot 001 \\
2,000 \\
0 \cdot 005 \mathrm{ml} \\
0 \cdot 25 \\
0 \cdot 5 \mathrm{ml} \\
2,000 \\
50 \\
50 \\
10\end{array}$ \\
\hline
\end{tabular}

(1) Salt-free hydrochloric acid hydrolysate of casein, Sheffield Chemicals, Norwich, N.Y. Dissolve in 21 . of de-ionized water with gentle heating and stirring.

(2) California Foundation for Biochemical Research, Los Angeles, Calif.

(3) Solutions $(10 \mathrm{mg} . / \mathrm{ml}$.) prepared by adding 1 g. chromatographically pure reagent to $25 \mathrm{ml}$. de-ionized $\mathrm{H}_{2} \mathrm{O}$, gently heating with added pellets of $\mathrm{KOH}$ until reagent dissolved, making up to final volume of $100 \mathrm{ml}$. with deionized $\mathrm{H}_{2} \mathrm{O}$. Store in refrigerator with volatile preservative added.

(4) Dissolve in $\mathrm{KOH}$ before adding.

(5) Solution ( $1 \mathrm{mg} . / \mathrm{ml}$.) prepared by dissolving $0.1 \mathrm{~g}$ : reagent in $100 \mathrm{ml}$. de-ionized $\mathrm{H}_{2} \mathrm{O}$. Store in refrigerator with volatile preservative added.

(6) Store in amber polyethylene bottle (6026, Cole-Parmer Instrument and Equipment Co., Chicago, Ill.) to protect from light.

(7) Solution $(0.08 \mathrm{mg} . / \mathrm{ml}$.) prepared by dissolving $8 \mathrm{mg}$. biotin in $100 \mathrm{ml}$. de-ionized $\mathrm{H}_{2} \mathrm{O}$. Store in refrigerator with volatile preservative added.

(8) Atlas Powder Co., Wilmington, Del. The viscous commercial preparation (specific gravity $=1$ ) is diluted 1:10 with water containing some ethanol to reduce foaming.

(9) One ml. contains: $\mathrm{MgSO}_{4} \cdot 7 \mathrm{H}_{2} \mathrm{O}, 40 \mathrm{mg}$.; $\mathrm{NaCl}, 2 \mathrm{mg}$.; $\mathrm{MnSO}_{4}$ $4 \mathrm{H}_{2} \mathrm{O}, 2 \mathrm{mg}$.; $\mathrm{FeSO}_{4} \cdot 7 \mathrm{H}_{2} \mathrm{O}, 2 \mathrm{mg}$.; Make $500 \mathrm{ml}$. by dissolving $20 \mathrm{~g}$. of $\mathrm{MgSO}_{4} \cdot 7 \mathrm{H}_{2} \mathrm{O} 2 \mathrm{~g}$. of $\mathrm{NaCl}, 1 \mathrm{~g}$. of $\mathrm{MnSO}_{4} \cdot 4 \mathrm{H}_{2} \mathrm{O}$, and $1 \mathrm{~g}$. of $\mathrm{FeSO}_{4} \cdot 7 \mathrm{H}_{2} \mathrm{O}$ in de-ionized water, add $1 \mathrm{ml}$. concentrated $\mathrm{HCl}$, store with volatile preservative added.

(10) Added after $p \mathrm{H}$ of assay medium adjusted to $6 \cdot 6$ to $6 \cdot 8$ with 0.1 $\mathrm{N} \mathrm{H}_{2} \mathrm{SO}_{4}$.
TABLE III

MAINTENANCE MEDIUM ${ }^{1}$

Constituent

Amount for Concentration in

$500 \mathrm{ml}$. Medium Final Medium

(g./100 ml.)

Yeast extract (Difco)

Proteose peptone (Difco)

Glucose

$\mathrm{KH}_{2} \mathrm{PO}_{4}$

Tomato juice filtrate ${ }^{2}$

Tween $80^{3}$

L-cysteine $\mathrm{HCl}$

\begin{tabular}{cc} 
& $(\mathrm{g} . / 100 \mathrm{ml})$. \\
\hline $3.75 \mathrm{~g}$. & 0.75
\end{tabular}

${ }^{1}$ Adjust to $p \mathrm{H} 6.8$ to 7 with $1 \% \mathrm{KOH}$. This medium, without the L-cysteine, has been previously described.

${ }^{2}$ Canned or vacuum-bottled tomato juice passed through coarse filter paper; straw-coloured filtrate adjusted to $p \mathrm{H} 7$ with $10 \% \mathrm{KOH}$.

'See footnote (8), Table I.

are tightened and the tubes incubated overnight at $37^{\circ} \mathrm{C}$. The following morning they are examined for clarity (indicating absence of bacterial contamination) and, if sterile, are then stored at $4^{\circ} \mathrm{C}$. until used.

At a maximal interval of once every two weeks, 1 drop of stored liquid culture is added to $10 \mathrm{ml}$. of fresh maintenance medium, incubated for 18 hours at $37^{\circ} \mathrm{C}$., and then stored at $4^{\circ} \mathrm{C}$. During the afternoon of the day before an assay, 1 drop of the latest stored culture is added to $10 \mathrm{ml}$. of maintenance medium and incubated for 18 hours at $37^{\circ} \mathrm{C}$. The next morning, $0.5 \mathrm{ml}$. of this fresh 18-hour culture is added to $10 \mathrm{ml}$. of maintenance medium and incubated for six hours at $37^{\circ} \mathrm{C}$. The inoculum for the assay is prepared by adding $0.5 \mathrm{ml}$. of this fresh six-hour culture to $10 \mathrm{ml}$. of single-strength basal medium. One drop of inoculum is added to each assay flask.

Volatile preservative, consisting of 1 part ethylene dichloride, 1 part monochlorobenzene, and 2 parts 1-chlorobutane, was then added to all stored solutions of assay medium and of buffer by spraying a small aliquot from a wash bottle into each solution after each use before returning to storage.

STANDARDS Three standard solutions of folic acid (pteroylmonoglutamic acid, P.G.A.) were prepared in $50 \mathrm{ml}$. aliquots, and stored between usages at $-20^{\circ} \mathrm{C}$. (no appreciable deterioration in two months): $10^{-8}$, $10^{-9}, 10^{-10}$ g. per ml. Crystalline P.G.A., $10 \mathrm{mg}$., is dissolved in $100 \mathrm{ml} .20 \%$ ethanol containing $1 \mathrm{ml}$. of

\section{TABLE II}

ASSAY PROTOCOL OF THE ASEPTIC ADDITION METHOD OF DETERMINATION OF FOLATE ACTIVITY IN SERUM

\begin{tabular}{llcc} 
Flask & & $\begin{array}{c}\text { Double-strength } \\
\text { Basal Medium }(\mathrm{ml} .)\end{array}$ & $\begin{array}{c}\text { Ion-fre } \\
(\mathrm{ml} .)\end{array}$ \\
\hline Number & Nature & & \\
\hline 1,8 & Control & 5 & 4 \\
2,9 & Standard & 5 & 3 \\
3,10 & Standard & 5 & 1 \\
4,11 & Standard & 5 & 3 \\
5,12 & Standard & 5 & 1 \\
6,13 & Standard & 5 & 3 \\
7,14 & Standard & 5 & 1 \\
15,16 & Unknown serum 1 & 5 & 4 \\
17,18 & Unknown serum 2 & 5 & 4
\end{tabular}

'Sodium phosphate buffer, $0.05 \mathrm{M}, p \mathrm{H} 6.1$, containing $1 \%$ ascorbic acid.

Folic Acid Serum $(\mathrm{ml}$.)

Standard $(\mathrm{ml}$.) 
$0 \cdot 1 \mathrm{~N} \mathrm{NaOH}$, to yield a $10^{-4} \mathrm{~g}$. per ml. solution of P.G.A. This concentrated stock solution is stored at $-20^{\circ} \mathrm{C}$., and is diluted with water to provide new aliquots of the standard solutions as they are used up; it does not deteriorate appreciably in a year.

With an automatic pipette, $5 \mathrm{ml}$. of double-strength basal medium was added to each $10 \mathrm{ml}$. micro-Fernbach flask (10 ml. Erlenmeyer flasks are less expensive, equally good, but more susceptible to tipping over; alternatively, test tubes may be used, but growth in them is slower). From 1 to $4 \mathrm{ml}$. of de-ionized water was next added to each flask, the volume being such as to bring the total volume in each flask to $10 \mathrm{ml}$. when all ingredients had been added.

Table II illustrates the assay protocol of the 'aseptic addition' method for the determination of folate activity in serum. After all ingredients except serum are added, the flasks are autoclaved for 30 minutes at 105 to $110^{\circ} \mathrm{C}$. then allowed to cool. Of each serum to be assayed, $0.1 \mathrm{ml}$. is added to one 'unknown' flask and $0.2 \mathrm{ml}$. to the other. The flasks are then all inoculated with $L$. casei.

One drop of inoculum is added to each flask, and the flasks incubated for 16 to 18 hours at $37^{\circ} \mathrm{C}$. Each flask is then vigorously shaken and its content transferred to a Klett (or other) colorimeter tube. Growth density is then measured with a Klett-Summerson or other photoelectric colorimeter using a red filter $(\lambda=640$ to $700 \mathrm{~m} \mu)$ to reduce error due to the colour of the medium. The optical densities representing growth of the standards are plotted on the geometric ordinate scale of semilogarithmic paper and the folate content of the standard is plotted on the logarithmic abscissa scale. The unknown sera then can have their folate content determined from this curve. The standards are run in duplicate, the results averaged, and the average values plotted. The curve should rise in slightly concave fashion (concave side up) until the $1 \times 10^{-8}$ standard, and then should level off; for this reason the $3 \times 10^{-8}$ standard need not be plotted on the graph.

ASSAY MEDIUM The preparation of the assay medium ${ }^{1}$ is described in Table I; it is, however, now commercially available. These 'dry mixes' must be stored refrigerated to avoid deterioration; to prepare the assay medium from them, just add water and stir.

PHOSPHATE BUfFer The sodium phosphate buffer is prepared as follows: dissolve $27 \cdot 6 \mathrm{~g}$. of $\mathrm{NaH}_{2} \mathrm{PO}_{4} \cdot \mathrm{H}_{2} \mathrm{O}$ in 1 1. distilled water (solution $\mathrm{A}$ ); dissolve $71 \cdot 6 \mathrm{~g} . \mathrm{Na}_{2} \mathrm{HPO}_{4}$. $12 \mathrm{H}_{2} \mathrm{O}$ in 1 l. distilled water (solution B). To $212.5 \mathrm{ml}$. of solution $A$ add $37.5 \mathrm{ml}$. of solution $B$; dilute to 11 . with de-ionized water. The $p H$ should be $6 \cdot 1$. Store solutions at room temperature with volatile preservative added.

\section{SUMMARY OF TECHNIQUE}

All glassware used in the assay must be folate-free, i.e., all flasks, beakers, etc., must have been boiled for 30

'Baltimore Biological Laboratory, 2201 Aisquith Street, Baltimore 18 Maryland, and Difco Laboratory, Detroit, Michigan, U.S.A.

${ }^{2}$ Meinecke and Co., New York, N.Y. minutes in $\mathrm{Hemosol}^{2}$ solution (or $7 \times$ solution or other $\underline{\overrightarrow{0}}$ strong blood-dissolving detergent) and then must have been rinsed 12 times with tap water and three times with distilled water.

The maximum convenient number of flasks for one assay is 114 , as that is the number of $10 \mathrm{ml}$. micro-

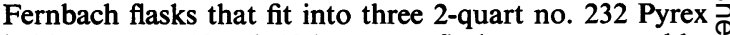
baking trays; $10 \mathrm{ml}$. Erlenmeyer flasks are acceptable, as are test tubes. Micro-Fernbach flasks are preferred because they tip over less easily.

1 The evening before the planned assay, inoculate $\vec{\circ}$ tube with $L$. case $i$ for 16-18 hour growth as follows: from $\overrightarrow{\vec{c}}$ the last 16-18 hour growth (stored in refrigerator at $4 \omega$ to $6^{\circ} \mathrm{C}$.) (safe storage period three weeks) inoculate 1 drop $\frac{}{\circ}$ into $10 \mathrm{ml}$. of fresh maintenance medium. Place in the? incubator at approximately 5 p.m. and let it remain $\overrightarrow{0}$ overnight at $37^{\circ} \mathrm{C}$.

2 First thing in the morning, prepare six to eight $\overrightarrow{\mathrm{N}}$ hour growth as follows:-Take $0.5 \mathrm{ml}$. of the $16-18$ hour $\mathrm{O}$ growth and inoculate that amount into a fresh tube of $10 \mathrm{ml}$. of maintenance medium. Shake. Store the $16-18-$ hour growth in a rack in a refrigerator. Incubate the newly inoculated tube for six to eight hours, i.e., till approximately $4 \mathrm{p.m}$. It is from the six-to-eight-hour growth that the assay flasks will be inoculated.

3 Thaw the three P.G.A. standards, which should be always kept in amber or brown plastic bottles, by removing from freezer and placing in the incubator at $37^{\circ} \mathrm{C}$. Remove from incubator before completely thawed, i.e., with a sliver of ice still present, and complete thawing at room temperature. Standards, i.e., solutions with known amounts of pteroylmonoglutamic acid, contain $1 \times 10^{-10}$, 응 $1 \times 10^{-9}, 1 \times 10^{-8} \mathrm{~g} . / \mathrm{ml}$.

4 Number flasks (10 ml. micro-Fernbachs) as follows: $\overrightarrow{\bar{O}}$ mark one 'LC' (this will be the $L$. casei dilution flask), 3 number flasks 1-14 (for standard curve in duplicate), number two flasks for each unknown, i.e., 15,16 for first unknown, 17, 18 for second unknown, etc.

5 Make up buffer-ascorbate by adding $1 \mathrm{~g}$. ascorbic acid just before use, because ascorbate in solution 0 deteriorates rapidly, to each $100 \mathrm{ml}$. of phosphate buffer (which is stored on a shelf at room temperature).

6 With automatic syringe set at $1 \mathrm{ml}$. put $1 \mathrm{ml}$., of ascorbate buffer into each flask except the dilution (LC) flask. Rinse syringe with distilled water.

7 Add $5 \mathrm{ml}$. double-strength assay medium (storea in brown plastic bottle in refrigerator, marked ' $2 \times L$. casei') to each micro-Fernbach flask. Add volatile preservative if necessary to brown bottle before returning. to refrigerator after use. (Sniff mouth of flask; if strong 0 odour of volatile preservative is not present, add it.)

Each micro-Fernbach flask gets $5 \mathrm{ml}$. medium. For this, use an automatic syringe. Use large (folate-free) beaker, and fill with medium. Try not to overestimate the quantity since more will have to be made up sooner if you do. Add $5 \mathrm{ml}$. medium to each flask.

8 Add de-ionized water with automatic syringe as follows: $5 \mathrm{ml}$. to dilution (LC) flask; $4 \mathrm{ml}$. to flasks nos. 1 우 and 8 (standard curve); $4 \mathrm{ml}$. to unknown; $3 \mathrm{ml}$. toळ standard curve flasks nos. $2,9.4,11,6,13 ; 1 \mathrm{ml}$. to standard curve flasks nos. $3,10,5,12,7,14$.

9 Add standard solutions, i.e., known amounts of 
pteroylmonoglutamic acid. Be sure that they are thawed but not warm; a tiny remaining sliver of ice should have just dissolved when solutions are used and then returned to the freezer.

$\begin{array}{lll}\text { 1Flasks no. 2, } 9 & \text { get } 1 \mathrm{ml} . & \text { of } 1 \times 10^{-10} \text { standard } \\ \text { Flasks no. 3, 10 } & \text { get } 3 \mathrm{ml} . & \text { of } 1 \times 10^{-10} \text { standard } \\ \text { Flasks no. 4, } 11 & \text { get } 1 \mathrm{ml} . & \text { of } 1 \times 10^{-8} \text { standard } \\ \text { Flasks no. } 5,12 & \text { get } 3 \mathrm{ml} . & \text { of } 1 \times 10^{-9} \text { standard } \\ \text { Flasks no. } 6,13 & \text { get } 1 \mathrm{ml} . & \text { of } 1 \times 10^{-8} \text { standard } \\ \text { Flasks no. } 7,14 & \text { get } 3 \mathrm{ml} . & \text { of } 1 \times 10^{-8} \text { standard }\end{array}$

'For pipetting standard solutions and adding standards to flasks, use $10 \mathrm{ml}$. blow-out pipettes. Fill to the $8 \mathrm{ml}$. mark with the standard you are using. Put $1 \mathrm{ml}$. in each of the two flasks that get $1 \mathrm{ml}$.; put $3 \mathrm{ml}$. in the two flasks getting $3 \mathrm{ml}$. each.

10 Get out three Pyrex dishes (2-quart trays). Place the flasks in numerical order in the trays and cover with metal or glass caps.

11 Autoclave the flasks in the Pyrex trays for 30 minutes at $225^{\circ} \mathrm{F}$. Set time at $30 \mathrm{~min}$., temp. dial on $\mathrm{O}$ of ' $230^{\circ}$ '. Check water level of autoclave and if necessary fill with distilled (de-ionized) water. Turn on autoclave. After 30 min., at 225 to $230^{\circ} \mathrm{F}$., turn off autoclave.

12 Let trays cool for approximately half an hour.

13 Get sera (unknowns) which you are running from freezer. Sera take approximately 45 minutes to thaw.

14 When the sera have thawed and trays have cooled, add $0.1 \mathrm{ml}$. of sera (unknown) to flrst unknown flask and $0.2 \mathrm{ml}$. to second unknown flask. For this, use $0.5 \mathrm{ml}$. pipettes (blow-outs); fill to $0.3 \mathrm{ml}$. and place $0.1 \mathrm{ml}$. in one of the two flasks and $0.2 \mathrm{ml}$. in the other.

15 Inoculate between 3 p.m. and 5 p.m. (remember six-to-eight-hour growth requires six to eight hours).

Put $0.5 \mathrm{ml}$. of the six-to-eight-hour growth into flask marked 'LC'. This must be done with aseptic technique. Mix thoroughly by rotating flask, or stirring with pipette (sterile). Take sterile $1 \mathrm{ml}$. pipette, flame tip (briefly). Let tip cool. Fill pipette with solution in freshly-stirred 'LC' flask. Place one drop in each flask including standard curve flask.

16 Since $L$. case $i$ falls into the facultative anaerobe category, the following steps should be taken before incubation overnight: the Pyrex trays with the capped flasks must be covered by an inverted Pyrex tray. Tape the sides of the trays together with masking tape. Place the trays in the incubator overnight.

17 The following morning glance at the bottoms of standard curve flasks. If the flasks have been incubated long enough a definite increase in the amount of growth will be evident in the flasks with each stepwise higher concentration of pteroylmonoglutamic acid; if this increase is not evident to the naked eye, incubate for two or more hours.

18 Read the assay. The colorimeter must be turned on approximately 20 minutes before using (warm-up necessary). Colorimeter must be properly adjusted with blank. Take out a colorimeter tube. Pour contents of the flasks one by one immediately after vigorously shaking flask into colorimeter tube, read. Pour contents back into flasks. As you go, record as indicated in the data book.
19 Graph the standard curve.

20 Calculate the unknowns in terms of the standard curve.

\section{DISCUSSION}

The aseptic addition method here described has been in use since 1960 in our studies in Boston and New York, and is also now being used by people to whom we have supplied the details in other American cities, Puerto Rico, South America, and England. The validity of the assay is unaffected by various minor changes in assay method or medium, provided contamination of glassware or ingredients by folate is excluded. (The commercial grade ingredients, especially casein and glucose, from many drug firms are contaminated with sufficient folate to invalidate the assay.) Both the assay medium and the maintenance medium we use (Baker, Herbert, Frank, Pasher, Hutner, and Wassermann, 1959; Herbert, 1961) are almost identical to prior media such as described by Jukes in 1955 . The validity of the assay resides not in minor changes in method or medium, but rather in the use of $L$. case $i$ as the assay organism and in the use of a reducing agent to protect folate against oxidative destruction. This is because the major folate in human serum appears to be N5 methyltetrahydro folic acid (Herbert, Larrabee, and Buchanan, 1962), on which $L$. casei grows but Streptococcus faecalis and Pediococcus cerevisiae (Leuconostoc citrovorum) do not grow.

The use of a reducing agent such as ascorbate to protect serum $L$. casei folate activity from destruction during the course of the assay is crucial because serum $L$. casei folate activity is highly labile. In our experience (Herbert, 1962), as well as that of Davis and Kelly (1962), the addition of ascorbate to serum before storage by freezing at $-20^{\circ} \mathrm{C}$. is not necessary to preserve folate. Waters and Mollin (1961) found some decline in serum $L$. casei folate activity when serum was stored at $-20^{\circ} \mathrm{C}$. without added ascorbate; Chanarin and Berry (1964) also reported some decline without added ascorbate. Spray (1964) confirmed our report (Herbert, 1961) that ascorbate stimulates the growth response of L. casei, and also presented data supporting the contention that there may be loss of folate activity of serum stored for 12 weeks at $-15^{\circ} \mathrm{C}$. Unlike these workers, we do not add $5 \mathrm{mg}$. ascorbate per millilitre of serum during storage periods preceding assay, partly because we have not found any deterioration after storage up to two years and partly because added ascorbate renders specimens less suitable for vitamin $B_{12}$ assay because of the destructive effect of ascorbate on the natural forms of vitamin $B_{12}$ present in human serum (Smith, 1965). 
A very important methodological consideratic $n$ is cleanliness to avoid contamination with folate. Contamination with micro-organisms is rarely a problem because of the rapidity with which $L$. case $i$ grows and makes lactic acid. Also important is refrigeration of media to avoid deterioration, and the aforementioned preservation of serum against oxidative destruction.

Since 1960 , we have assayed 4,500 sera by the aseptic addition method. Interpretation of results is as indicated in Table IV. While the aseptic addition

TABLE IV

\begin{tabular}{ccr}
$\begin{array}{c}\text { INTERPRETATION OF SERUM L. CASEI FOLATE VALUES } \\
\text { Interpretation }\end{array}$ & Folate & $\begin{array}{r}\text { Number } \\
\text { of samples }\end{array}$ \\
\hline Low & 3 & 1,036 \\
Suggestive of deficiency & $3-4 \cdot 9$ & 317 \\
Indeterminate & $5-6 \cdot 9$ & 399 \\
Normal & $7-15 \cdot 9$ & 2,161 \\
Indeterminate & $16-25$ & 334 \\
High & $>25$ & 253 \\
Folate values are in nanograms $\left(10^{-9} \mathrm{~g}.\right) / \mathrm{ml}$. &
\end{tabular}

method generally gives results essentially identical to the standard method, it occasionally yields significantly higher results. We interpret this as due to the greater preservation of highly labile serum folates, present to variable degree in different sera, by the larger ascorbate concentration, and also to the lack of exposure of the serum to autoclaving such as occurs in the standard method.

Tetracycline antibiotics suppress $L$. casei growth, yielding false low results. This fact must be kept in mind when interpreting results with sera from patients receiving antibiotic therapy.

\section{ADDENDUM}

Harper (1965) has recently reported a modified aseptic addition assay procedure for the measurement of serum folate activity. His paper confirmed

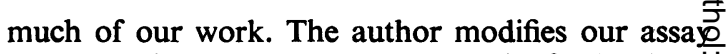
procedure in two ways. He reduces the final volume from $10 \mathrm{ml}$. to $4 \mathrm{ml}$; this has value when only? $0.04 \mathrm{ml}$. of serum can be obtained instead of $0.1 \mathrm{mlo}$ for assay. He deletes phosphate buffer, stating tha the buffering capacity of the assay medium is sufficiently good and the extra buffer is superfluous $\mathrm{He}$ also states that 'the assay medium of Watery and Mollin with additional L-tryptophan is used instead of the assay medium of Herbert'. In fact this 'assay medium of Waters and Mollin' with additionat L-tryptophan is our assay medium. They used oup medium but deleted tryptophan. By again addin tryptophan, Harper has made the assay medium as we originally described it.

I am deeply indebted to the following technician co요 workers: Becky Fisher Dunn, Becky Jo Koontz, Nancy Cunneen Boardman, Brenda Conti Dicken, Mary Ellen Spector, Mary Small, Virginia Chapin, Peter Mason, anథึ Leona Bandel.

This work was supported by U.S.P.H.S. grants AM 09564, AM 09062, the Albert A. List, Frederick Machlinand Anna Ruth Lowenberg Funds, and a Health Researcio Council career scientist award from the City of New York.

\section{REFERENCES}

Baker, H., Herbert, V., Frank, O., Pasher, I., Hutner, S. H., Wasse: man, L. R., and Sobotka, H. (1959). Clin. Chem., 5, 275. Chanarin, I., and Berry, V. (1964). J. clin. Path., 17, 111.

Davis, R. E., and Kelly, A. (1962). Aust. J. exp. Biol. med. Sci., 40, 437

Harper, T. A. (1965). Nature (Lond.), 207, 947.

Herbert, V. (1961). J. clin. Invest., 40, 81.

- (1962). Med. Clin. N. Amer., 46, 1365.

— (1964). Proc. roy. Soc. Med., 57, 377.

- (1965). Ann. Rev. Med., 16, 359. - Larrabee, A. R., and Buchanan, J. M. (1962). J. clin. Invest., 41 .
1134.

- Wasserman, L. R., Frank, O., Pasher, I., and Baker, H. (1959) Fed. Proc., 18, 246.

Jukes, T. H. (1955). Meth. biochem. Anal., 2, 121.

Smith, E. L. (1965). Vitamin $B_{12}$. Methuen, London.

Spray, S. H. (1964). J. clin. Path., 17, 660.

Waters, A. H., and Mollin, D. L. (1961). Ibid., 14, 335. 